\title{
dr Lidia Kłos*
}

\section{STYL ŻYCIA MLODZIEŻY AKADEMICKIEJ}

\author{
STYLE OF LIFE AMONG ACADEMIC YOUTH
}

\begin{abstract}
The aim of this article is to define a balanced lifestyle and VS conception and also to interpret a functioning youth's lifestyle. For this purpose a life balance test was conducted which will make it possible to point out essential components of balance between private life and professional life or university life of our respondents.

The surveys were conducted on a Steering Group of 104 students of the third year of undergraduate full-time and external studies in the years 2017 and 2018. An analysis of the main components was used to explain the research.

The conclusions about balanced lifestyle of academic youth will be enunciated based on the results.
\end{abstract}

Keywords: balanced lifestyle, voluntary simplicity, consumerism, conscious consumer

JEL classification: Q01, Q25, Q32, Q56

\section{Wstęp}

Równowaga w życiu jest niezwykle ważna - od tego, czy uda nam się je sprawnie zorganizować i wypełnić wszystkie zadania, zależy nasze samopoczucie, ale też poczucie samorealizacji. Obecnie coraz trudniej jest nam znaleźć równowagę między życiem zawodowym a życiem prywatnym - im bardziej skupiamy się na jednym, tym bardziej cierpi druga sfera. Ma to również związek z panującym edu.pl

* Uniwersytet Szczeciński, Wydział Nauk Ekonomicznych i Zarządzania; Lidia.Klos@usz. 
obecnie konsumpcyjnym stylem życia - przekonaniem, że ciągłe nabywanie dóbr i ich konsumowanie jest drogą do osiągnięcia szczęścia i pełnej satysfakcji oraz podniesienia swojego statusu społecznego. Skutki braku równowagi życiowej widoczne są zarówno w wymiarze środowiskowym, ekonomicznym, jak i społecznym, prowadzą przy tym do pogorszenia jakości życia obecnych i przyszłych pokoleń.

Celem artykułu jest zdefiniowanie zrównoważonego stylu życia i koncepcji VS oraz próba określenia stylu życia młodzieży. Przeprowadzono w związ$\mathrm{ku} \mathrm{z}$ tym test na równowagę życiową oraz sondaż diagnostyczny w postaci kwestionariusza ankiety ze zrównoważonej konsumpcji, który pozwoli wskazać istotne elementy równowagi między życiem prywatnym a zawodowym czy uczelnianym respondentów. Badania ankietowe przeprowadzono na pilotażowej grupie 104 studentów III roku studiów licencjackich stacjonarnych i zaocznych w roku akademickim 2017/2018. Do interpretacji badań wykorzystano metodę analizy głównych składowych. Na podstawie otrzymanych wyników zostaną sformułowane wnioski odnośnie do stylu życia młodzieży akademickiej.

\section{Przejawy i formy stylu życia}

Mimo bardzo szerokiego zastosowania pojęcia „styl życia” („sposób życia”) zarówno w literaturze socjologicznej, jak i ekonomicznej kategoria ta nie doczekała się jednoznacznego zdefiniowania. Najczęściej styl życia określa się jako obserwowalne codzienne zachowania konsumenta, jak i nieobserwowalne wartości, które te zachowania kształtują ${ }^{1}$. W tym ujęciu styl życia definiuje się jako cały zbiór wartości, zainteresowań, poglądów i zachowań konsumenta, które wpływają na jego zachowania konsumpcyjne ${ }^{2}$. Zwraca się też uwagę na indywidualne wzorce działania, zainteresowań i przekonań, którymi konsumenci różnią się między sobą ${ }^{3}$. Styl życia determinuje zatem wybory kształtujące codzienne funkcjonowanie jednostki i tym samym wpływa na jej tryb życia, a więc na specyficzny, charakterystyczny dla danej osoby sposób zachowania w konkretnym momencie ${ }^{4}$.

${ }^{1}$ L. Rudnicki, Zachowania konsumentów na rynku, Polskie Wydawnictwo Ekonomiczne, Warszawa 2012, s. 107.

${ }^{2}$ G. Antonides, W.F. van Raaij, Zachowanie konsumenta, Wydawnictwo Naukowe PWN, Warszawa 2003, s. 385.

${ }^{3}$ G. Kuś, Decyzje zakupowe konsumentów a systemy komunikowania, Novae Res, Gdynia 2011, s. 77.

${ }^{4}$ S.L.T. McGregor, Sustainable life path concept: journeying toward sustainable consumption, „Journal of Research for Consumers” 2013, Issue 24, s. 38. 
W konsekwencji przyjęty czy preferowany styl życia jest istotnym czynnikiem warunkującym zachowania konsumentów ${ }^{5}$.

Podstawowym aspektem codziennego życia jednostki związanym z zaspokojeniem jej potrzeb jest konsumpcja. Styl życia społeczeństwa konsumpcyjnego i łączące się z nim dylematy opisuje m.in. W. Muszyński w książce pod jego redakcją ,Nowy wspaniaty świat”? Moda, konsumpcja i rozrywka jako nowe style $\dot{z} y c i a^{6}$. Konsumpcja nie jest wartością samą w sobie, tylko środkiem zaspokojenia podstawowych potrzeb jednostki, jak również potrzeb wyższego rzędu, które stają się źródłem przyjemności współczesnego człowieka ${ }^{7}$. Problem pojawia się wówczas, kiedy człowiek sprowadza swoje życie do potrzeby konsumowania, co przejawia się w nadmiernym nabywaniu dóbr i usług, znacznie przekraczającym indywidualne potrzeby, w myśl zasady, że lepiej mieć więcej niż mniej ${ }^{8}$. Efektem jest zjawisko nadkonsumpcji, której przyczyną jest dewaluacja pierwotnego znaczenia zaspokajania potrzeb. Konsekwencje nadkonsumpcyjnego stylu życia w wymiarze ekonomicznym, społecznym i ekologicznym ponoszą już obecne, a będą ponosić też przyszłe pokolenia9

Przeciwieństwem nadkonsumpcyjnego stylu życia są formy zachowań konsumenta, które wynikają z pewnych wartości i poglądów, a prowadzą do podejmowania przez niego decyzji o rezygnacji z konsumpcji lub ograniczeniu nabywania niektórych dóbr. W praktyce wyraża się to przez świadome ograniczenie spożycia do racjonalnych rozmiarów wynikających z naturalnych, indywidualnych, fizycznych i psychicznych cech konsumenta ${ }^{10}$. W literaturze przedmiotu wymienia się trzy grupy motywów wyznaczających trzy wymiary dekonsumpcji: konsumpcję asekuracyjną, serwicyzację oraz konsumpcję zrównoważoną ${ }^{11}$. Konsumpcja asekuracyjna (zabezpieczająca) oznacza ograniczenie konsumpcji ze względu na dynamiczne zmiany otoczenia potencjalnie lub faktycznie naruszające stabilność sytuacji ekonomicznej jednostki i jej gospodarstwa domowego.

${ }_{5}^{5}$ C. Bywalec, Konsumpcja $w$ teorii i praktyce gospodarowania, Wydawnictwo Naukowe PWN, Warszawa 2007, s. 34-35.

${ }^{6}$ „Nowy wspaniały świat”? Moda, konsumpcja i rozrywka jako nowe style życia, red. W. Muszyński, Wydawnictwo Adam Marszałek, Toruń 2009.

${ }^{7}$ M. Golka, Nowe style zachowań, Wydawnictwo Fundacji Humaniora, Poznań 2001, s. 171.

${ }^{8}$ B. Mróz, Dyskretny urok konsumpcjonizmu. Szkic do portretu konsumenta XXI wieku, [w:] Życie w konsumpcji, konsumpcja w życiu. Psychologiczne ścieżki wspótzależności, red. A.M. Zawadzka, M. Górnik-Durose, Gdańskie Wydawnictwo Psychologiczne, Sopot 2010, s. 211-212.

${ }^{9}$ L. Kłos, Świadomość ekologiczna Polaków - przeglad badań, „Zeszyty Naukowe Wydziału Nauk Ekonomicznych i Zarządzania. Studia i Prace Uniwersytetu Szczecińskiego", t. 2, nr 42, Wydawnictwo Naukowe Uniwersytetu Szczecińskiego, Szczecin 2015, s. 35-45. Od 1992 roku Instytut na rzecz Ekorozwoju przeprowadza regularne badania na temat świadomości ekologicznej mieszkańców Polski.

${ }^{10}$ C. Bywalec, L. Rudnicki, Konsumpcja, Polskie Wydawnictwo Ekonomiczne, Warszawa 2002, s. 143.

${ }^{11}$ J. Woś, J. Rachocka, M. Kasperek-Hoppe, Zachowania konsumentów: teoria i praktyka, Wydawnictwo Uniwersytetu Ekonomicznego w Poznaniu, Poznań 2011, s. 157. 
Tak rozumiana dekonsumpcja staje się dla człowieka koniecznością, a nie wyborem, którego by dokonał w innych warunkach rynkowych (np. dysponując wyższym dochodem). Drugi wymiar dekonsumpcji wynika z obserwowanej w krajach wysoko rozwiniętych serwicyzacji, tj. zwiększania w konsumpcji udziału usług. Za jej sprawą spada spożycie dóbr materialnych, a spadek ten jest kompensowany wzrostem konsumpcji produktów niematerialnych - usług. W praktyce oznacza to jakościowe, a nie ilościowe zmiany spożycia, konsumenci bowiem zaspokajają ten sam zestaw swoich potrzeb, który w ich odczuciu nie wiąże się z koniecznością rezygnacji z konsumpcji czy wprowadzenia ograniczeń w bieżącym spożyciu. Trzeci wymiar dekonsumpcji łączy się z dążeniem jednostek do konsumpcji zrównoważonej, zawierającej w sobie przesłanki ekologiczne, społeczne, a także motywy związane z przestrzeganiem zasad moralnych i wymiarem duchowym. Ten wymiar dekonsumpcji zakłada oszczędne gospodarowanie zasobami w celu zachowania równowagi biologicznej i stworzenia dla przyszłych pokoleń warunków życia nie gorszych niż obecne ${ }^{12}$. W odróżnieniu od konsumpcji asekuracyjnej jest on związany z wolnym wyborem, a w przeciwieństwie do serwicyzacji oznacza celowe wprowadzenie ograniczeń i pełną akceptację „życia z mniejszą ilością produktów” i jego ,uproszczenia”. Oznacza to świadome i celowe dekonsumpcyjne zachowania jednostek stanowiące przeciwieństwo konsumpcyjnego stylu życia i nadkonsumpcji ${ }^{13}$.

\section{Zrównoważona konsumpcja jako wyznacznik współczesnego stylu życia}

Wyrazem dążenia do zrównoważonego stylu życia jest po stronie popytowej wykształcenie się zjawiska zrównoważonej konsumpcji. Pojęcie zrównoważonej konsumpcji po raz pierwszy pojawiło się w trakcie konferencji Organizacji Narodów Zjednoczonych w sprawie środowiska i rozwoju w Rio de Janeiro w 1992 roku $^{14}$. Dzisiejsze ramy polityczne działań w sprawie zrównoważonej konsumpcji oparte są na Deklaracji z Johannesburga, przyjętej podczas Światowego Szczytu Zrównoważonego Rozwoju w 2002 roku, oraz na procesie z Marrakeszu z 2003 roku. Także Strategia zrównoważonego rozwoju UE, uaktualniona w 2006 roku, uznała zrównoważoną konsumpcję za jedno z siedmiu

12 Wykorzystując w tym zakresie dorobek ekonomii środowiska, por. H. Rogall, Ekonomia zrównoważonego rozwoju. Teoria i praktyka, Wydawnictwo Zysk i S-ka, Poznań 2010, s. 25.

${ }_{13} \mathrm{~J}$. Zrałek, Voluntary simplicity - zrównoważony styl życia współczesnych konsumentów, „Studia Ekonomiczne. Zeszyty Naukowe Uniwersytetu Ekonomicznego w Katowicach”, nr 231, Katowice 2015, s. 142.

${ }^{14}$ P. Macnaghten, J. Urry, Alternatywne przyrody. Nowe myślenie o przyrodzie i społeczeństwie, Wydawnictwo Naukowe Scholar, Warszawa 2005, s. 284-285. 
najważniejszych wyzwań stojących przed współczesnymi społeczeństwami ${ }^{15}$. Konsumpcja zrównoważona jest definiowana jako „taka struktura systemu konsumpcji, w ramach której kształt poszczególnych układów oraz związki i zależności między nimi umożliwiają realizację celów zrównoważonego rozwoju, w efekcie konsumpcji współczesnego pokolenia nie ogranicza się możliwości konsumpcji przyszłych generacji"16.

Odpowiedzią jest rozwój i funkcjonowanie społeczeństwa zainteresowanego zrównoważonym stylem życia, wiernego koncepcji Voluntary Simplicity (VS, dobrowolna prostota ${ }^{17}$ ). Wymaga to nauczenia się nowych zachowań i uznania wartości pod wieloma względami różniących się od tych, którym hołduje społeczeństwo konsumpcyjne. Pojęcie ,zrównoważony styl życia” i wpisująca się w jego idee koncepcja VS mają na uwadze dobrostan obecnego i przyszłych pokoleń. Wyrazem tego jest ruch dobrowolnej prostoty, w którym podkreśla się znaczenie zachowania równowagi między ludzkimi potrzebami a zasobami środowiska przyrodniczego.

Promowanie postawy polegającej na świadomej rezygnacji z nieuzasadnionego konsumowania dóbr, propagowanie prostego stylu życia, upowszechnienie się ruchu dobrowolnej prostoty (voluntary simplicity movement) ${ }^{18}$ to zjawiska, które można było zaobserwować w Stanach Zjednoczonych już na początku XX wieku, jednak stały się one ważnym elementem publicznej debaty dopiero w latach 70 .

15 T. Zalega, Sustainable consumption and innovative consumption in consumer behaviour of Mazovian households, „Handel Wewnętrzny” 2014, nr 4, s. 312.

${ }^{16}$ D. Kiełczewski, Konsumpcja a perspektywy zrównoważonego rozwoju, Wydawnictwo Uniwersytetu w Białymstoku, Białystok 2008, s. 60; O. Mont, A. Plepys, Sustainable consumption progress: should we be proud or alarmed?, „Journal of Cleaner Production” 2008, No. 16, s. 532. W literaturze przedmiotu brak powszechnej zgody co do definicji zrównoważonej konsumpcji, dlatego proponuje się, aby zrównoważoną konsumpcję traktować jako pojęcie ,parasol", które obejmuje takie zagadnienia jak: potrzeby człowieka, sprawiedliwość, jakość życia, efektywność wykorzystania zasobów, minimalizacja powstawania odpadów, myślenie w kategoriach długości cyklu produktów, zdrowie i bezpieczeństwo konsumenta, suwerenność konsumenta. W literaturze krajowej o zrównoważonej konsumpcji pisali m.in.: T. Borys, Problemy zrównoważonej konsumpcji, [w:] Rozwój zrównoważony: teoria i praktyka, red. B. Fiedor, R. Jończy, Uniwersytet Ekonomiczny we Wrocławiu, Wrocław 2009; idem, Zrównoważony rozwój i jakość życia człowieka czyli krótka historia o trzech drogach i postawach życiowych, „Ekonatura” 2011, $\mathrm{nr}$ 5, s. 28-30; B. Kryk, Zrównoważona jakość życia a zrównoważona konsumpcja i zachowania ekologiczne polskich konsumentów, „Handel Wewnętrzny: marketing, rynek, przedsiębiorstwo”, R. 59, t. 2, nr 6A, Warszawa 2013, s. 5-19.

${ }^{17}$ Koncepcja Voluntary Simplicity (VS), dobrowolnej prostoty, stanowi praktyczną realizację postulatu zrównoważenia konsumpcji zawartego we wszystkich najważniejszych dokumentach międzynarodowej polityki ochrony środowiska naturalnego - np. w Agendzie 21 czy postanowieniach Szczytu Ziemi w Johannesburgu (S. Alexander, The voluntary simplicity movement: reimagining the good life beyond consumer culture, „The International Journal of Environmental, Cultural, Economic \& Social Sustainability" 2011, Vol. 7, Issue 3, s. 139).

${ }^{18}$ L.S. Rockefeller, The case for a simpler life-style, ,Reader's Digest” 1976, February, s. 61-65; C. Henderson, The frugality phenomenon, „Economic Review” 1979, April-May, s. 28-30. 
$\mathrm{XX}$ wieku $^{19}$. Rozważania na ten temat pogłębił S. Zavestowski, który stwierdził, że teoria Maslowa pozwala wyjaśnić relację między pojawieniem się antykonsumpcyjnych postaw konsumenckich a poczuciem satysfakcji (szczęścia) wynikającym z postrzegania przez konsumenta „własnego ja" ${ }^{20}$. Według tego autora na poczucie osiągnięcie szczęścia składa się: poczucie własnej wartości, wiara we własne umiejętności i poczucie autentyczności (prawdziwości). Zavestowski przełożył te wartości na konkretne potrzeby. Poczucie własnej wartości odpowiada potrzebie szacunku, a potrzeba wiary we własne umiejętności i potrzeba autentyczności składają się na potrzebę samorealizacji. Na podstawie badań przeprowadzonych wśród bogatych społeczeństw krajów rozwiniętych uznał, że w przeciwieństwie do pozostałych potrzeb, potrzeby autentyczności człowiek nie jest w stanie zaspokoić za pomocą materialnej konsumpcji. Drogą do tego celu jest bowiem prosty styl życia, w którym ważniejsze od konsumpcji jest budowanie relacji międzyludzkich. Zmiany wprowadzone przez Zavestowskiego do hierarchii potrzeb Maslowa przedstawia rysunek 1.

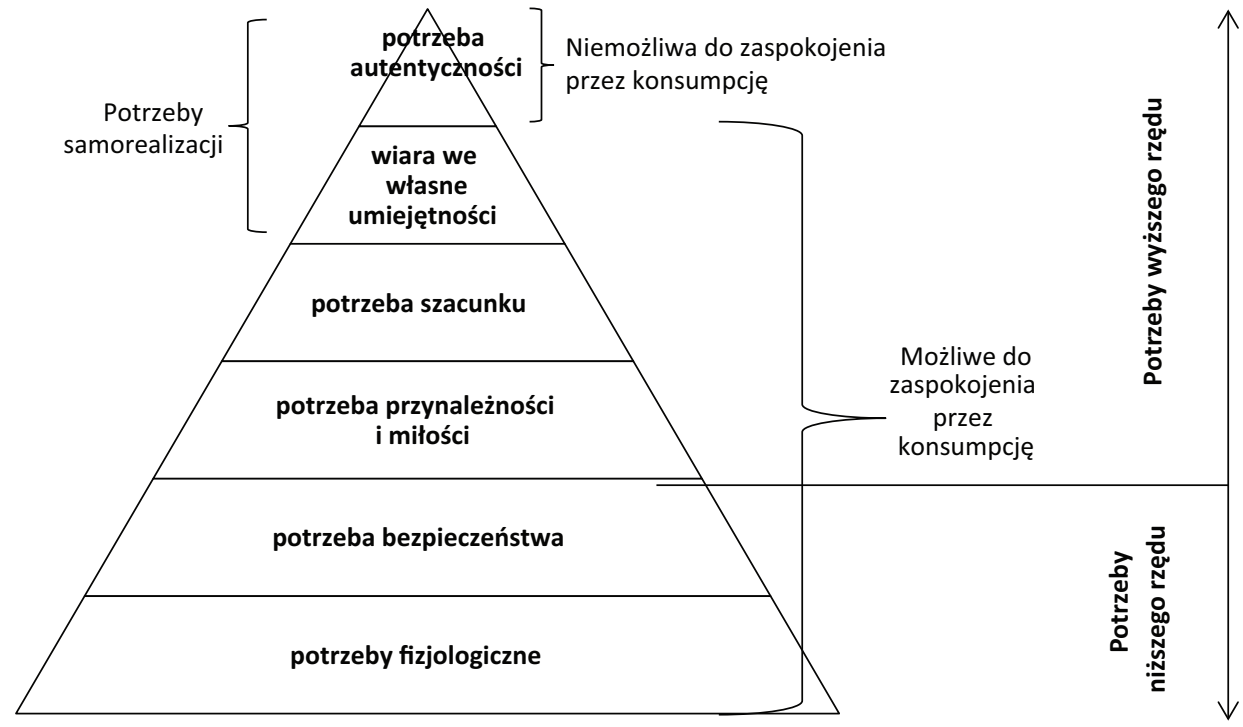

Rysunek 1. Zmiany w piramidzie potrzeb Maslowa

Źródło: S. Zavestoski, The social-psychological bases of anticonsumption attitudes, „Psychology \& Marketing" 2002, Vol. 19, No. 2, s. 156.

${ }_{19}$ B. Bengamra-Zinelabidine, On the concept of voluntary simplicity towards marketing, „Asian Journal of Business and Management Sciences” 2011, Vol. 2, No. 1, s. 185.

${ }^{20}$ S. Zavestoski, The social-psychological bases of anticonsumption attitudes, „Psychology \& Marketing" 2002, Vol. 19, No. 2, s. 155-156. 


\section{Metodyka badań}

Badania wśród studentów przeprowadzono w roku akademickim 2017/2018 na 104-osobowej grupie respondentów z kierunku Finanse i rachunkowość, III rok licencjatu studiów stacjonarnych i zaocznych ${ }^{21}$. To pokolenie Polaków urodzonych w latach 90. XX wieku, określane bardzo często jako „pokolenie Y - dzieci wolnego rynku". Dojrzewało w czasach, kiedy postawy życiowe młodych ludzi kształtowały się pod wpływem ideologii sukcesu i konsumpcjonizmu globalnej kultury $^{22}$, dlatego panuje powszechne przekonanie, że jest to pokolenie skazane na konsumpcyjny styl życia.

I tak $73 \%$ grupy badawczej stanowiły kobiety, $69 \%$ badanych respondentów było mieszkańcami miasta. Skala wiekowa badanej grupy oscyluje w przedziale 21-26 lat, przy czym trzy osoby były w wieku 32 lat.

Wyniki badań pokazują, że 10\% badanych odwiedza centra handlowe kilka razy w tygodniu, 40\% kilka razy w miesiącu, 39\% rzadziej niż raz w miesiącu, a zaledwie $4 \%$ nie bywa tam wcale. Według badania aż 63\% studentów (70\% kobiet i $56 \%$ mężczyzn) udaje się do centrów handlowych nie tylko na zakupy, ale również w celach rozrywkowych.

W hierarchii ważności wydatków studentów na pierwszym miejscu pojawiła się chęć posiadania mieszkania. Niemal połowa (48\%) jego nabycie traktuje głównie jako dobrą inwestycję, nieco mniej (40\%) chciałoby dokonać takiego zakupu w celu założenia rodziny - w tej grupie przeważają studenci niestacjonarni (53\%) i taki właśnie cel posiadania mieszkania wyraża 36\% studentów pracujących i tylko $18 \%$ studentów niepracujących ${ }^{23}$.

Zachowania osób prezentujących orientację prokonsumpcyjną cechuje skłonność do zakupów mimo deklarowanego negatywnego do nich nastawienia. Strukturę zachowań konsumpcyjnych uwzględniającą podział na płeć przedstawia tabela 1.

Tabela 1. Pleć a zachowania konsumpcyjne (w \%)

\begin{tabular}{|l|c|c|}
\hline \multicolumn{1}{|c|}{ Wyszczególnienie } & Kobiety & Mężczyźni \\
\hline Zakupy to dla mnie konieczność & 2 & 16 \\
\hline Nie lubię zakupów, ale chęć nabywania jest większa & 38 & 24 \\
\hline Często dokonuję spontanicznych zakupów & 10 & 10 \\
\hline
\end{tabular}

Źródło: opracowanie własne na podstawie badań.

${ }^{21}$ Wybór studentów tego kierunku podyktowany był wyłącznie liczebnością grupy.

${ }^{22}$ K. Szafraniec, Anemia okresu transformacji a orientacje życiowe młodzieży, [w:] Kondycja moralna spoleczeństwa polskiego, red. J. Mariański, Wydawnictwo WAM, Kraków 2002, s. $454-455$.

${ }^{23}$ Szerzej na temat badania w zakresie zrównoważonej konsumpcji w gospodarstwie domowym w: H. Rogall, Ekonomia zrównoważonego rozwoju..., s. 206-210. 
Więcej kobiet (38\%) niż mężczyzn (24\%) nie lubi zakupów, jednak ma do nich skłonność. Mężczyźni (16\%) częściej niż kobiety (zaledwie 2\%) zakupy uważają za konieczność. Taki sam odsetek obu płci (po 10\%) przyznaje się do robienia spontanicznych zakupów. Zdecydowana większość badanych (72\%) wyraża pogląd, że kupowanie pozwala im zaspokajać swoje potrzeby. W zakresie kontroli zakupów i racjonalnych decyzji zdania są podzielone. Niemal połowa (42\%) twierdzi, że kupuje rzeczy najbardziej niezbędne, ale 30\% badanych nie jest tego pewna. Podobny odsetek badanych twierdzi, że „raczej nie” i „zdecydowanie nie" kupuje rzeczy niezbędnych.

Interesujące są również opinie na temat zachowań dekonsumpcyjnych związanych z prowadzeniem ,zdrowego stylu życia”. Większość uważa je za wymóg zdrowia (54\% badanych), sprawdzian silnej woli (34\%), a także przedłużenie życia i młodości (24\%), choć przestrzeganie zasad zdrowego stylu życia znacznie się obniża (tab. 2).

Tabela 2. Poglądy studentów w kwestii zdrowego stylu życia i ich zachowania w tym obszarze (w \%)

\begin{tabular}{|l|c|c|}
\hline \multicolumn{1}{|c|}{ Wyszczególnienie } & $\begin{array}{c}\text { Pogląd w kwestii } \\
\text { zdrowego stylu życia }\end{array}$ & $\begin{array}{c}\text { Przestrzeganie zasad } \\
\text { zdrowego stylu życia }\end{array}$ \\
\hline Przedłużenie zdrowia i młodości & 24 & 14 \\
\hline Wymóg zdrowia & 54 & 24 \\
\hline Sprawdzian silnej woli & 34 & 20 \\
\hline Moda & 22 & 4 \\
\hline Wyraz dbania o własne ciało & 18 & 8 \\
\hline Sposób na zachowanie zgrabnej sylwetki & 10 & 10 \\
\hline
\end{tabular}

Źródło: opracowanie własne na podstawie badań.

Wśród preferowanych sposobów spędzania wolnego czasu dominują: kino (41\%), siłownie i clubbing (po 38\%), hobby i lektura w domu (po 36\%) oraz spacer (35\%). Szczegółowy rozkład preferencji w tym zakresie przedstawia tabela 3.

Wyniki ankiety uzupełniono badaniem nad stanem równowagi życiowej wśród studentów. Do tego celu wykorzystano Test na równowagę życiową opracowany przez dr. Jacka Sobka ${ }^{24}$. Składa się on z 27 pozycji testowych i służy do oszacowania trzech wymiarów równowagi życiowej, takich jak praca, rodzina i środowisko, w którym żyjemy.

${ }_{24}$ J. Sobka, Test na równowagę życiową, https://www.farmacjapraktyczna.pl/2012/05/test-zyciuppanuje-rownowaga, 2012 [dostęp: 20.04.2018]. 
Tabela 3. Preferowane sposoby spędzania wolnego czasu przez studentów

\begin{tabular}{|l|l|}
\hline \multicolumn{1}{|c|}{ Wyszczególnienie } & \% \\
\hline Shopping* & 19 \\
\hline Zakupy & 24 \\
\hline Hobby & 36 \\
\hline Lektura w domu & 35 \\
\hline Spacer & 21 \\
\hline Teatr & 29 \\
\hline Posiłki w restauracji & 41 \\
\hline Kino & 38 \\
\hline Siłownia/clubbing & 21 \\
\hline Zwiedzanie zabytków & 29 \\
\hline Wycieczki rowerowe & 28 \\
\hline Wycieczki piesze & 23 \\
\hline Basen & 17 \\
\hline Siłownia & 18 \\
\hline Fitness & 22 \\
\hline Wycieczki zagraniczne & 36 \\
\hline
\end{tabular}

* Shopping - pojęcie szersze niż „zakupy”, zawierające w sobie sposób spędzania czasu, przyjemne przeżycia i doznania, które temu towarzyszą (M. Górnik-Durose, Kupowanie rzeczy, kupowanie doświadczeń - nowe zjawiska w zachowaniach konsumenckich, [w:] Psychologiczne uwarunkowania zachowań ekonomicznych. Przedsiębiorczość - pieniądze - konsumpcja, red. M. Goszczyńska, M. Górnik-Durose, Difin, Warszawa 2010, s. 212-213).

Źródło: opracowanie własne na podstawie badań.

Osoba badana, odpowiadając na poszczególne pozycje testu, w czteropunktowej skali określa prawdziwość twierdzeń opisujących przekonania, postawy i zachowania dotyczące rożnych sytuacji życiowych. Wyniki uzyskiwane przez badanych oblicza się zgodnie z wskazaną punktacją, według której liczba poniżej 32 punktów oznacza, że dana osoba dobrze sobie radzi w znajdowaniu balansu między pracą a życiem osobistym. Wynik w przedziale 33-64 punktów wskazuje, że osoba badana prawdopodobnie potrzebuje pracy nad wybranymi obszarami, aby uzyskać lepszą równowagę życiową. Osiągnięcie 65 i więcej punktów to stan, który oznacza, że dana osoba boryka się z konsekwencjami braku równowagi w życiu zawodowym i prywatnym. 
Równowaga życiowa

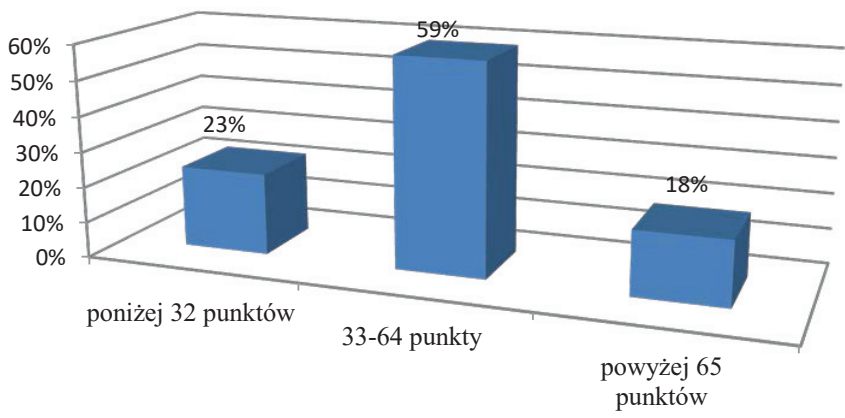

Wykres 1. Test na równowagę życiową

Źródło: badanie własne.

W badaniu studentów otrzymano następujące wyniki: poniżej 32 punktów znalazło się 32\% badanych respondentów, w przedziale 33-64 punktów odpowiedziało $59 \%$ studentów, a $18 \%$ uzyskało powyżej 65 punktów. Oznacza to, że blisko $1 / 5$ badanych studentów już teraz ma trudności z równoważeniem życia osobistego i zawodowego.

\section{Zakończenie}

W Polsce, podobnie jak w innych krajach Europy Środkowej i Wschodniej, nadkonsumpcyjny oraz konsumpcyjny styl życia to zjawiska stosunkowo nowe. Polacy nie mieli wystarczająco dużo czasu, aby nasycić się możliwościami zaspokojenia potrzeb, jakie daje wolnorynkowa gospodarka. Młodym konsumentom może być więc trudno w wystarczającym stopniu kontrolować swoje potrzeby konsumpcyjne. Dominacja konsumpcyjnego stylu życia jest niejako wpisana w strategię życiową ,pokolenia Y”. Chyba że skutecznie zadziała tu mechanizm naśladownictwa społecznego i popularyzacji dekonsumpcyjnych zachowań i zdrowego stylu życia konsumentów z Europy Zachodniej.

Porównując obie badane grupy, należy stwierdzić, że dominacja wzorów racjonalnych w konsumpcji widoczna jest w grupie studentów pracujących (w tym studiujących zaocznie). Natomiast obie grupy posiadają wysokie aspiracje w dziedzinie konsumpcji, mające charakter częściej potrzeb odłożonych i planowanych na okres po studiach, związany z osiągnięciem stabilizacji życiowej i samodzielności finansowej.

Podsumowując badania, należy stwierdzić, że 23\% studentów umie sobie radzić z zachowaniem równowagi życiowej. Ponad połowa z nich (59\%) wymaga niewielkiej pomocy i wsparcia $\mathrm{w}$ obszarze godzenia życia prywatnego 
z uczelnianym/zawodowym. Natomiast $18 \%$ nie jest w stanie już na tym etapie pogodzić życia osobistego z zawodowym.

Determinanty zrównoważonego stylu życia należy postrzegać przede wszystkim w kontekście zmian w postawach, hierarchiach wartości oraz przemianach kulturowych polskiego społeczeństwa. Jednocześnie zmiana stylu życia nie jest w wypadku badanej grupy niemożliwa. Wymaga ona jednak samodyscypliny i swoistej „odporności” na pokusy konsumpcyjnego świata.

\section{Bibliografia}

Alexander S., The voluntary simplicity movement: reimagining the good life beyond consumer culture, ,The International Journal of Environmental, Cultural, Economic \& Social Sustainability" 2011, Vol. 7, Issue 3.

Antonides G., van Raaij W.F., Zachowanie konsumenta, Wydawnictwo Naukowe PWN, Warszawa 2003.

Bengamra-Zinelabidine B., On the concept of voluntary simplicity towards marketing, „Asian Journal of Business and Management Sciences" 2011, Vol. 2, No. 1.

Borys T., Problemy zrównoważonej konsumpcji, [w:] Rozwój zrównoważony: teoria i praktyka, red. B. Fiedor, R. Jończy, Uniwersytet Ekonomiczny we Wrocławiu, Wrocław 2009.

Borys T., Zrównoważony rozwój i jakość życia człowieka czyli krótka historia o trzech drogach i postawach życiowych, „Ekonatura” 2011, nr 5, s. 28-30.

Bywalec C., Konsumpcja w teorii i praktyce gospodarowania, Wydawnictwo Naukowe PWN, Warszawa 2007.

Bywalec C., Rudnicki L., Konsumpcja, Polskie Wydawnictwo Ekonomiczne, Warszawa 2002.

Golka M., Nowe style zachowań, Wydawnictwo Fundacji Humaniora, Poznań 2001.

Górnik-Durose M., Kupowanie rzeczy, kupowanie doświadczeń - nowe zjawiska w zachowaniach konsumenckich, [w:] Psychologiczne uwarunkowania zachowań ekonomicznych. Przedsiębiorczość - pieniądze - konsumpcja, red. M. Goszczyńska, M. Górnik-Durose, Difin, Warszawa 2010.

Henderson C., The frugality phenomenon, „Economic Review” 1979, April-May, s. 28-30.

Kiełczewski D., Konsumpcja a perspektywy zrównoważonego rozwoju, Wydawnictwo Uniwersytetu w Białymstoku, Białystok 2008.

Kłos L., Świadomość ekologiczna Polaków - przeglad badań, „Zeszyty Naukowe Wydziału Nauk Ekonomicznych i Zarządzania. Studia i Prace Uniwersytetu Szczecińskiego”, t. 2, nr 42, Wydawnictwo Naukowe Uniwersytetu Szczecińskiego, Szczecin 2015.

Kryk B., Zrównoważona jakość życia a zrównoważona konsumpcja i zachowania ekologiczne polskich konsumentów, „Handel Wewnętrzny: marketing, rynek, przedsiębiorstwo”, R. 59, t. 2, nr 6A, Warszawa 2013, s. 5-19.

Kuś G., Decyzje zakupowe konsumentów a systemy komunikowania, Novae Res, Gdynia 2011.

Macnaghten P., Urry J., Alternatywne przyrody. Nowe myślenie o przyrodzie i społeczeństwie, Wydawnictwo Naukowe Scholar, Warszawa 2005.

McGregor S.L.T., Sustainable life path concept: journeying toward sustainable consumption, „Journal of Research for Consumers" 2013, Issue 24, s. 33-56.

Mont O., Plepys A., Sustainable consumption progress: should we be proud or alarmed?, „Journal of Cleaner Production" 2008, No. 16. 
Mróz B., Dyskretny urok konsumpcjonizmu. Szkic do portretu konsumenta XXI wieku, [w:] Życie $w$ konsumpcji, konsumpcja $w$ życiu. Psychologiczne ścieżki wspótzależności, red. A.M. Zawadzka, M. Górnik-Durose, Gdańskie Wydawnictwo Psychologiczne, Sopot 2010.

„Nowy wspaniały świat”? Moda, konsumpcja i rozrywka jako nowe style życia, red. W. Muszyński, Wydawnictwo Adam Marszałek, Torun 2009.

Rockefeller L.S., The case for a simpler life-style, „Reader's Digest” 1976, February, s. 61-65.

Rogall H., Ekonomia zrównoważonego rozwoju. Teoria i praktyka, Wydawnictwo Zysk i S-ka, Poznań 2010.

Rudnicki L., Zachowania konsumentów na rynku, Polskie Wydawnictwo Ekonomiczne, Warszawa 2012.

Sobka J., Test na równowagę życiową, https://www.farmacjapraktyczna.pl/2012/05/test-zyciuppanuje-rownowaga, 2012 [dostęp: 20.04.2018].

Szafraniec K., Anemia okresu transformacji a orientacje życiowe młodzieży, [w:] Kondycja moralna społeczeństwa polskiego, red. J. Mariański, Wydawnictwo WAM, Kraków 2002.

Woś J., Rachocka J., Kasperek-Hoppe M., Zachowania konsumentów: teoria i praktyka, Wydawnictwo Uniwersytetu Ekonomicznego w Poznaniu, Poznań 2011.

Zalega T., Sustainable consumption and innovative consumption in consumer behaviour of Mazovian households, „Handel Wewnętrzny” 2014, nr 4.

Zavestoski S., The social-psychological bases of anticonsumption attitudes, „Psychology \& Marketing" 2002, Vol. 19, No. 2.

Zrałek J., Voluntary simplicity - zrównoważony styl życia współczesnych konsumentów, „Studia Ekonomiczne. Zeszyty Naukowe Uniwersytetu Ekonomicznego w Katowicach”, nr 231, Katowice 2015, s. 139-158.

\section{Streszczenie}

Analiza relacji między stylami życia współczesnego społeczeństwa a perspektywami zrównoważonego rozwoju jest zagadnieniem istotnym badawczo, którego podjęcie może pozwolić uzyskać odpowiedź na pytania: ,Jak styl życia współczesnej młodzieży ma się do koncepcji zrównoważonego stylu życia?”, „Czy w przyszłości młodzież będzie sobie radziła z równoważeniem sfery życia rodzinnego i zawodowego?”. W Polsce można zauważyć wyraźną lukę badawczą związaną z brakiem szerszego omówienia zagadnienia zrównoważonego stylu życia i koncepcji dobrowolnej prostoty (Voluntary Simplicity - VS) w grupie młodzieży. Brak badań z tego zakresu uniemożliwia jednoznaczne stwierdzenie, jak polska młodzież (obecni i przyszli konsumenci) ocenia zrównoważony styl życia i czy jest w stanie dobrowolnie zaadaptować się do jego zasad. Próba podjęcia dyskusji na ten temat jest celem niniejszego opracowania. Artykuł ma charakter koncepcyjny i stanowi próbę wypełnienia wskazanej luki badawczej.

Słowa kluczowe: zrównoważony styl życia, dobrowolna prostota, konsumpcjonizm, świadomy konsument

Numer klasyfikacji JEL: Q01, Q25, Q32, Q56 